\title{
MODERN PARADIGM OF NATIONAL INTERESTS PROMOTING IN FOREIGN ECONOMIC ACTIVITY OF SLOVAKIA
}

\author{
Kostyantyn Flissak ${ }^{1}$, Tetiana Drakokhrust ${ }^{2}$
}

\begin{abstract}
The aggravation of competition processes in international economic relations leads to the fact that individual business entities do not have the opportunity to effectively represent themselves abroad. In such circumstances, the importance of state support and promotion of national interests abroad significantly increases. The purpose of the article is to explore and analyse the practice of economic diplomacy in Slovakia from the point of view of an impartial researcher, aimed at improving the national system for promoting national interests abroad. To achieve this goal, the research is focused on following tasks: to consider and analyse the main trends in the formation and development of economic diplomacy in Slovakia, to perform a brief analysis of the practice of foreign economic activity in Slovakia, highlighting its main positive and negative aspects; to summarize the main strengths of the Slovak system of promoting national interests abroad in order to recommend them for use in the practice of other countries, in particular Ukraine. Methodology. In the process of preparation the article, methods of scientific abstraction, observation, synthesis, generalization, as well as statistical and economic methods were used to determine the effectiveness of Slovak foreign economic activity and the influence of the state on it. The information and analytical base for the study includes the regulatory framework of the European Union and the Slovak Republic, materials and analytical reports of international organizations dealing with the considerate issues (UNCTAD, WTO, World Bank), regulatory and statistical data of Slovak state authorities, the results of research by modern scientists from different countries. The results of the study show that the economic diplomacy of the Slovak Republic within the framework of its EU membership is an important tool for the success of the country's foreign economic policy, ensuring its export expansion in international markets and intensive investment cooperation with foreign investors. Particularly remarkable is the current practice of staffing institutions of economic diplomacy in Slovakia, which is based on qualified training of economic diplomats within the framework of a full-fledged university programmes. In the prospect professional support for the structures of Slovak economic diplomacy and its personnel, professional, structural and financial support from the Ministry of economy becomes a requirement. The practical implications of the scientific research is to find out the current state of economic diplomacy mechanisms in individual European countries, trends in their development and potential consequences for the economic potential of other states (in particular, Ukraine) based on the introduction of effective mechanisms for promoting national interests abroad. Value/originality. The mechanisms and practices of promoting Slovakia's foreign economic activity in foreign economic relations deserve the attention of the relevant state structures of Ukraine regarding the unification of regulatory standards and the formation of appropriate mechanisms for protecting national interests, including in the context of the implementation of the Ukraine-European Union Association Agreement. In addition, this study has significant potential for further consideration in subsequent scientific publications.
\end{abstract}

Key words: national interests, foreign economic activity, export, investment, diplomacy, Slovak Republic.

JEL Classification: F13, F23, O24

\footnotetext{
Corresponding author:

${ }^{1}$ West Ukrainian National University, Ukraine.

E-mail: Flissak.K@ukr.net

ORCID: https://orcid.org/0000-0002-0980-2398

ResearcherID: P-9986-2018

${ }^{2}$ West Ukrainian National University, Ukraine.

E-mail: tanya.drakohrust@gmail.com

ORCID: https://orcid.org/0000-0002-4761-7943

ResearcherID: G-7287-2017
} 


\section{Introduction}

Achieving success in the full integration of Ukraine into the world economy system and ensuring the implementation of its European integration aspirations is possible, firstly, due to the necessary development of its own productive forces, achieving the appropriate level of economic development and socio-economic standards, and secondly, to the unification of normative and legal bases and standards of regulating the economy with the norms and mechanisms in force in the EU. The priority here remains protecting and effectively promoting national interests in international relations in such a way as to achieve the most complete consistency between the Ukrainian interests and the imperatives of developing the foreign economic activity of the EU member states. Substantiation of vectors for solving such problems should be based on maximum consideration of the mentioned activities of partner countries and, above all, Ukraine's neighbours along the EU borders. In this regard, the considerable interest belong to the analysis of the functioning of mechanisms for promoting national interests in the field of foreign economic cooperation by the EU countries close to Ukraine in terms of natural resource potential and economic structure. At the same time, the proper level of efficiency of their foreign economic activity should be taken into account. The Slovak Republic is a partner for Ukraine. However, the problem of promoting national interests in foreign economic activity in the context of a globalized world economic system and growing competition in international markets is relevant for other countries, not only in Central and Eastern Europe.

The issues of mechanisms and tools for promoting national interests in foreign economic activity in the global level are considered in the scientific publications by a number of foreign authors, in particular N. Bayne (2007), S. Woolcock (2007, 2016), A.K. Rose (2007), S. Moons (2009), P.A.G. Van Bergeijk (2009, 2011), S. Bayne (2010), M. Okano-Heijmans, J. Melissen (2011), B. Glasser (2012), A.F. Cooper, J. Heine, R. Thakur $(2013,2015)$. To the problems of direct activity of the state and relevant institutions of Slovakia are devoted articles by such authors as L. Marchichiakova (2014), R. Bohac, L. Lipkova (2016), M. Fabus (2014), M. Kurucz (2018).

At the same time, there are currently no publications that would comprehensively demonstrate the functioning of the mechanism for assistance and promoting Slovakia's national interests in its foreign economic activity, its features in the context of the country's membership in the European Union and with taking into account the aggravation of competition in globalized markets.

Thus there is a need of consideration and systematization of the functioning of mechanisms and instruments of influence and assistance of the state and authorized institutions to improve the efficiency of foreign economic activity in the area of international trade and investment partnership, determination of the modern paradigm of ensuring and promoting Slovakia's national economic interests in international cooperation. On this basis it is possible to attract attention of the relevant state structures of Ukraine to unify regulatory standards and form appropriate mechanisms for protecting national interests in the context of the implementation of The EU-Ukraine Association Agreement. Given the relevance of the topic for implementation in national practice in the countries concerned, the purpose of this article is also to focus not so much on theoretical discussions on the definitions of elements of foreign economic activity, but on the practical actions of Slovakia in ensuring the effective promotion of national interests in foreign markets.

\section{Foreign economic activity of Slovak business and its legal regulation}

Contradictions and the latest challenges of the current stage of world development, the emergence of new centres of economic activity, increased competition between countries and international regional structures force the governments of countries to modernize the system and mechanisms for protecting and promoting of national interests in the area of international economic relations. Despite its membership in the EU, for the Slovak Republic this led to the formation of an appropriate paradigm in ensuring the effectiveness of export-import relations and investment activities in the part of attracting foreign investments, the development of foreign economic relations on a cooperative basis both within the EU and as a part of the Visegrad Four, as well as with other countries. A specific feature of this paradigm in recent years is a pronounced pro-export policy of the state. Its implementation is largely ensured by means of the economic diplomacy. Thus, among the four main pillars of foreign and European policy indicated in the report of the Ministry of Foreign Affairs to the National Council under the name "Goals of Foreign and European Policy of the Slovak Republic for 2014", there were highlighted economic diplomacy and a joint presentation of the country abroad (L. Marchichiakova, 2014).

The country's national interests in the foreign economic sphere are primarily provided by export activities. The World Bank data is shown in Table 1, indicate the level of export orientation of the country's gross domestic product (GDP).

The share of exports in Slovakia's GDP ranged from $73 \%$ in 2010 to $88.4 \%$ in 2018 , and on average over the past decade, exports have generated $84.4 \%$ of the 
Table 1

Export share of Slovakia GDP (in billion USD)

\begin{tabular}{|c|c|c|c|}
\hline & Export & GDP & $\begin{array}{c}\text { Share of export in } \\
\text { GDP, } \%\end{array}$ \\
\hline $\mathbf{2 0 1 0}$ & 65.96 & 90.31 & 73.0 \\
\hline $\mathbf{2 0 1 1}$ & 79.74 & 99.12 & 80.5 \\
\hline $\mathbf{2 0 1 2}$ & 80.72 & 94.54 & 85.4 \\
\hline $\mathbf{2 0 1 3}$ & 85.70 & 98.85 & 86.7 \\
\hline $\mathbf{2 0 1 4}$ & 86.23 & 101.19 & 85.2 \\
\hline $\mathbf{2 0 1 5}$ & 75.15 & 88.47 & 84.9 \\
\hline $\mathbf{2 0 1 6}$ & 77.06 & 89.66 & 85.9 \\
\hline $\mathbf{2 0 1 7}$ & 83.41 & 95.49 & 87.4 \\
\hline $\mathbf{2 0 1 8}$ & 93.42 & 105.70 & 88.4 \\
\hline $\mathbf{2 0 1 9}$ & 89.62 & 105.08 & 85.3 \\
\hline
\end{tabular}

Source: compiled by the author based on data by The World Bank (2020)

country's GDP. This is one of the highest rates for both the EU and other Eastern European countries. For example, during the reviewed period, the level of export orientation of Poland's GDP averaged 40.6\%, and Ukraine's was $38.0 \%$. The high export orientation, and consequently the dependence from export of Slovakian GDP, was due to: firstly, the high material content of export items from national producers; secondly, providing of high quality of Slovak export products and their compliance with international standards; thirdly, the use of effective mechanisms for supporting and promoting national products in foreign markets.

Slovakia's foreign trade is characterized by (with some exceptions) a positive balance; there are Germany, the Czech Republic, Poland, Hungary,
France, Italy, the Russian Federation, China, and the Republic of Korea among its main trading partners. The dynamics of the geographical structure of the country's Export-Import Operations for 20102019 is shown in Table 2. The given structure characterizes the geographical vectors of Slovakia's foreign trade over the past decade.

The performed research shows that the success of promoting Slovakian products in foreign markets and development of its new segments in a large extent is provided exactly by the state support for exports and investments and the full usage of economic diplomacy tools. The implementation of activities of economic diplomacy is provided in the following directions: 1) normative and legislative; 2) functional and institutional; 3) personnel; 4) methodological.

As the performed analysis shows, normative and legislative support at the legislative level is the basic and initial position of the success of the Slovakian economic diplomacy. Thus, the protection of Slovakia's interests in the external sphere is carried out in accordance with the "Strategy of foreign economic relations of the Slovak Republic for 2014-2020" (Ministry of Economy of the Slovak Republic, 2014). The core of the Strategy is the sphere of export policy as a priority direction of the state's foreign trade policy. The subject of this Strategy is the system of foreign economic relations of the Slovak Republic, through which the country participates in the international division of labour. Taking into account the need to form a significant impact on the international competitiveness of the country, the Strategy is aimed primarily at strengthening the

Table 2

Dynamics of the structure of exports and imports of the Slovak Republic, in percent

\begin{tabular}{|c|c|c|c|c|c|c|}
\hline \multirow{2}{*}{ Countries } & \multicolumn{3}{|c|}{ Export } & \multicolumn{3}{|c|}{ Import } \\
\hline & 2010 & 2017 & 2019 & 2010 & 2017 & 2019 \\
\hline Total & 100 & 100 & 100 & 100 & 100 & 100 \\
\hline \multicolumn{7}{|l|}{ - including: } \\
\hline EU-28 & 84.4 & 85.4 & 84.3 & 66.0 & 66.9 & 67.1 \\
\hline \multicolumn{7}{|l|}{ - among them: } \\
\hline Germany & 19.3 & 20.8 & 22.3 & 15.3 & 16.5 & 16.2 \\
\hline Czech Republic & 14.0 & 11.5 & 11.0 & 10.4 & 10.2 & 10.1 \\
\hline Italy & 5.6 & 6.0 & 4.6 & 3.2 & 3.2 & 3.4 \\
\hline Poland & 7.3 & 7.6 & 7.5 & 3.9 & 5.2 & 5.7 \\
\hline Hungary & 6.7 & 6.0 & 6.3 & 4.2 & 4.8 & 5.2 \\
\hline France & 6.9 & 6.3 & 7.0 & 3.5 & 3.2 & 3.5 \\
\hline Russian Federation & 3.9 & 2.0 & 1.8 & 9.6 & 4.7 & 5.6 \\
\hline Ukraine & 0.8 & 0.6 & 0.9 & 0.9 & 0.9 & 0.8 \\
\hline Asia & 5.3 & 4.6 & 4.9 & 19.9 & 23.0 & 21.3 \\
\hline \multicolumn{7}{|l|}{ - including: } \\
\hline China & 2.0 & 1.6 & 2.1 & 5.9 & 7.3 & 6.3 \\
\hline Republic of Korea & 0.2 & 0.1 & 0.4 & 7.8 & 5.7 & 5.4 \\
\hline Africa & 0.5 & 0.6 & 0.9 & 0.5 & 0.5 & 0.8 \\
\hline America & 2.3 & 3.7 & 4.2 & 1.4 & 1.7 & 1.8 \\
\hline
\end{tabular}

Source: compiled by the author based on data by Statistical office of the Slovak Republic (2019) 
national system of export support and its alignment with both the trends of the foreign economic conjuncture and the interests of the Slovakian business sector.

The Strategy of foreign economic relations of Slovakia is based on the following main principles:

1) compliance with international obligations arising from membership in the European Union and international organizations;

2) support of processes of liberalization in international business;

3) fulfilment of principles of the competition;

4) development of support mechanisms within building a transparent business environment;

5) taking into account the need of effective use of limited financial and human resources;

6) avoid of duplication of certain goals, procedures and instruments that are the subject of other strategic documents in the area of support of foreign investments, tourism, innovative cooperation with other countries, energy security and unified joint presentation of the Slovak Republic;

7) coordination of activities between the Ministry of Foreign and European Affairs of the Slovak Republic (MFEA), the Ministry of Economy and other organizations that are involved in the formation and implementation of the strategy of foreign economic relations in accordance with the legislation and the Memorandum of cooperation between these ministries in the realisation of the goals of economic diplomacy by the Slovakian offices abroad.

The main goals of the Strategy of foreign economic relations are to ensure the stable state of the Slovak Republic in international economic relations, to promote the economic and social development of the country, to promote economic interests abroad, to ensure the requirements of economic security.

According to the main target, the Strategy provided the achievement of goals in the following four areas: 1) trade policy; 2) investment activities; 3 ) scientific and innovative cooperation with foreign countries; 4) unified joint presentation of Slovakia abroad. The study confirmed the success of achieving defined goals.

In trade policy the Strategy defines its general regulations, objectives and directions of increasing both exports and number of exporters, ensuring stable supply of strategic goods. Taking into account the existing weaknesses of Slovakia, the trade policy section are determined the objectives and directions of territorial diversification of the export structure by increasing its share on markets outside Europe. In addition, there are identified the objectives regarding the need of exports diversification by increasing the exports share of electrical machinery, equipment, parts (HS85) and vehicles, other than railway or tramway rolling stock, parts and accessories (HS87). Also according to the Strategy, the objectives of Slovakia's trade policy are increasing the share of exports of small and medium enterprises and increase the volume of exports of services, including tourism.

Investment objectives of Strategy of foreign economic relations are associated to government programs and are focused on:

1) increasing investment flows to economic spheres with high value-added but located in less developed regions;

2) improving export performance through investments;

3) increasing of investments in industrial research and development;

4) supporting of investors in their activities in Slovakia.

The Strategy envisages that the implementation and verification (checking the status of the implementation of these positions) is performed by the Ministry of Economy of the Slovak Republic in close cooperation with the Ministry of Finance and the Ministry of Foreign and European Affairs (MFEA).

The Strategy refers next goals of innovative cooperation of Slovakia with foreign countries:

1) raising the level of involvement of Slovakian business and research institutions to international scientific cooperation projects;

2) increasing the internationalization level of the results of domestic research and development;

3 ) increasing of interest of foreign venture capital sources to projects by Slovakian enterprises;

4) increasing the interest from foreign companies to establishing their $R \& D$ centres in the Slovak Republic.

Particularly importance in promoting the national interests of the country abroad belongs to its qualified and effective representation abroad. Therefore, the Strategy of foreign economic relations clearly specified the goals in this important segment of foreign economic activity. In particular, it is necessary to ensure: firstly, the creation of a functional model of coordination of actors that take part in the presentation of Slovakia abroad; secondly, the establishment of a reliable, specific and attractive presentation of the identity of Slovakia.

The achievement of the main goal and implementation of the objectives of the Strategy of foreign economic relations is ensured, first of all, by the mechanisms and instruments of economic diplomacy of the Slovak Republic.

\section{Functional and institutional support of economic diplomacy}

Functional and institutional support of providing of national interests abroad by instruments of economic diplomacy is performed through the 
process of coordinated activities of the Slovakian government agencies and its special organizations and interdepartmental structures. The primary role here belongs to the Ministry of Foreign and European Affairs (MFEA) and the Ministry of Economy (ME SR) of the Slovak Republic. Important places in the promotion of national economic interests of Slovakia in foreign markets by means of economic diplomacy belong to the Slovak Government's Council for Export and Investments Promotion as well as the Slovak Investment and Trade Development Agency (SARIO).

Analysis of the practice of promoting Slovakian national interests in foreign trade and investment issues gives reasons to pay special attention to the significant role and its real effectiveness of the Ministry of Foreign and European Affairs of the Slovak Republic in the functioning of economic diplomacy (this practice is successfully applied in Poland (Yankiv, Flissak, Kozłowski, 2020) and we consider that it would be important for Ukraine, but, unfortunately, is absent here). In this context, the MFEA supports the promotion of exports, investment and research cooperation on the principles of international development, provides assistance to Slovakian companies through a network of foreign institutions in establishing contacts with foreign partners, identifies business and investment opportunities in host countries, creates conditions for the successful implementation of economic and trade cooperation at the highest political level, and provides functional support of export through tools of economic diplomacy.

In the structure of the MFEA the functional support of economic diplomacy is entrusted to the Economic cooperation section. It consists of Department of Global Policy, two Departments of Economic Diplomacy, the Department of Entrepreneurship Centre, and the Department of International Economic Organizations (Ministry of Foreign and European Affairs of the Slovak Republic). Formed by the MFEA, the foreign network consists of 64 institutions and representative offices with economic orientation. The network includes 49 systematic positions of economic diplomats. In addition, 173 consular offices (including those with the use of the Institute of honorary Consuls) abroad were actively involved in the performance of the functions of economic diplomacy in the departmental subordination of the MFEA (Ministry of Economy of the Slovak Republic, 2014).

The structures of MFEA, according to the competence and functional powers, both in the country and through a network of foreign institutions provides the following support and assistance to participants of foreign economic activity (Slovak Investment and Trade Development Agency - SARIO, 2020):
- consultations on the political, trade and economic, business environment in the host countries of the Slovak missions;

- providing on the request from Slovakian business structures the basic contact details and other information about foreign business entities which can be potential partners;

- providing information and assistance according to the requests and proposals of Slovakian exporters;

- search for business and investment opportunities in the host countries for Slovakian exporters;

- search for potential investors and regular dialogue with key partners in investment cooperation in the host countries;

- providing foreign companies with necessary information about potential Slovakian partners and their proposals for investment partnership;

- selection of relevant exhibitions abroad for the participation of Slovakian companies, providing consulting and organizational support for their participation in exhibitions;

- organization of business missions, intergovernmental economic commissions for cooperation between the Slovak Chamber of Commerce and Industry (SOPK), the Slovak Investment and Trade Development Agency (SARIO) and relevant ministries; - organization of seminars for exporters jointly with SOPK, SARIO, relevant industry and professional associations;

- promoting of international cooperation in science, research and innovation, energy and food security, climate change, consumption of water and raw material resources (identification of the Slovak projects, interests and options regarding finding ways to participate in relevant international and regional projects);

- support for the participation of Slovakian enterprises in regional cooperation (e.g., within the framework of the Central European initiative, the European Danube strategy, cross-border cooperation, partnership between regions, cities, municipalities etc);

- providing information and cooperation in the organization of participation of entrepreneurs and public administration institutions in the EU external assistance projects for third countries, in the organization of public procurement in rest of the world, in the establishing of international cooperation.

The Ministry of Economy of the Slovak Republic is the central authority of state administration in issues of foreign trade. Thus, the Ministry of Economy functionally ensures the following tasks in this area (Ministry of Economy of the Slovak Republic, 2020):

1) develops the main directions and objectives of the foreign trade policy of the Slovak Republic in the framework of active participation in the Committee of permanent representatives of the EU member states and other EU structures, participates in the development of 
common foreign trade policy of the European Union in relation to the World Trade Organization and other regional associations;

2) develops the main directions and objectives of the state project policy, ensures its implementation, generate mechanisms for the provision of state assistance for the development of foreign trade;

3 ) develops a system of measures for stimulation the inflow of foreign direct investments;

4) provides comprehensive international trade and economic cooperation in accordance with the membership of the Slovak Republic in the Organization for economic cooperation and development and other relevant international organizations;

5) develops, coordinates and ensures the implementation of multilateral and bilateral contracts in the sphere of foreign trade cooperation of the Slovak Republic with foreign countries;

6) vindicates the trade interests of the Slovak Republic in the use of trade protection instruments in committees and working groups of the European Commission and the Council of the European Union.

Normatively provided system of coordination of actions in economic diplomacy is a fundamentally important point in the performance of functional duties in the sphere of foreign economic activity of the Slovak Republic government structures, which ultimately determines its high efficiency. In addition to the foregoing personnel provision of economic diplomacy, the Ministry of Economy of the Slovak Republic closely cooperates with other ministries, central and regional entities of state administration. Particularly, the Ministry of Economy cooperates with the Ministry of Foreign and European Affairs on the following issues:

- development, implementation and providing of a joint foreign policy in the trade and economic sphere;

- public administration of imports, exports and intermediation by military goods and technologies which are subject to inspection;

- development of concepts and justification of principles of relations on participation in international economic or trade organizations;

- preparation, signing and implementation of international trade agreements;

- preparation of intergovernmental agreements in the scope of tourism and implementation of tasks arising from membership in the World Tourism Organization;

- solving specific tasks related to activity of foreign missions of the Slovak Republic, which provide international trade and economic cooperation and collaboration with economic or trade international organizations;

- contacting foreign representative offices of the Slovak Republic in the host countries and contacting representative offices of foreign states concerned to activities of Slovak business entities abroad and foreign entities in Slovakia.

Among the subjects of the national level of economic diplomacy there is the Slovak Government's Council for Export and Investments Promotion - the advisory, coordinating and initiative entity of the Government on the issues of state support of economic and trade cooperation, and presentation of the Slovak Republic (Ministry of Foreign Affairs and European Affairs of the Slovak Republic, 2020). The Council consists of: 1) heads of central executive authorities (Minister of Foreign and European Affairs, Minister of Economy, Minister of Finance, Secretary of State of the Ministry of Transport, Construction and Regional Development); 2) state financial institutions (representative of Export-Import Bank of Slovakia); 3) organizations of employers and commercial institutions (Slovak Chamber of Commerce and Industry, Association of Trade Unions and Employers' Associations of the Slovak Republic, National Employers' Union, Club 500, Slovak Association of Small and Medium Enterprises and Individual Entrepreneurs, Association of Industry Unions).

The statutory activities of the Government's Council for Export and Investments Promotion are focused on the following main tasks:

1) formation of proposals and conclusions to strategic documents of ministries and other central government entities in the area of support, investments, international presentations and other forms of international economic cooperation of the Slovak Republic;

2) evaluation of services which are provided by Slovak diplomatic missions as support to national business abroad and development of recommendations for their improvement;

3) submission of proposals on territorial priorities for the development of international trade, economic and investment cooperation of the Slovak Republic with foreign countries and the presentation of Slovakia abroad;

4) taking measures for coordinated actions of the business sector for more effective ensuring trade and economic interests of the Slovak Republic abroad in accordance with the adopted territorial priorities of development of international trade and economic cooperation, including a coordinated presentation of the Slovak Republic abroad;

5) cooperation with relevant committees of the National Council and with advisers of the Prime Minister of the Slovak Republic.

According to the functional responsibilities and actual needs of the country, the Government's Council for Export and Investments Promotion considers the relevant issues and takes the necessary decisions. Thus, in December 2016 at the meeting of the Council, the Ministry of Foreign and European Affairs was presented a document on the strategy 
of economic diplomacy until 2020. Its position was conceptually based on the Strategy of foreign economic relations of the Slovak Republic for the period 2014-2020 and the Government's programme declaration. At the first meeting of the Council in 2017, one of the key issues was considered the basis of the "White Book on Pro-Export Policy 2017", presented by the Ministry of economy of Slovakia. The document set new goals to strengthen the country's export orientation. At the same time, the Ministry of Foreign and European Affairs presented proposals on innovative forms of strengthening the potential of economic diplomacy. At the first meeting of the Council in 2018, one of the main issues for discussion and decision-making were priorities of the Slovak Republic's pro-export policy for the period 2018-2020. In addition, it was heard and discussed a report on the state and results of economic diplomacy of Slovakia in 2017.

An important place among the state subjects of economic diplomacy of the country belongs to the Slovak Investment and Trade Development Agency (SARIO), which is the state agency of Slovakia established under the Ministry of Economy of the Slovak Republic in 2001 with the aim of attracting of investments and promoting of national exporters on the global market.

In the scope of foreign trade SARIO provides the following services to exporters: searches for foreign trade partners in regions of interest; makes analysis of a demand for the products of interest in foreign markets; forms on-line database of business opportunities; provides education and training of specialists in the sphere of foreign trade; assists in search for subcontracting opportunities.

In promoting of investment activities, SARIO provides detailed information on the Slovak business environment, conditions for establishing the company, services related to immovable property and a number of others, including advisement on state support. For potential investors, SARIO offers: overview of the advantages of Slovakia as a place for investment, including the provision of key statistical indicators; making of sectoral and regional analyses; assistance in the realization of investment projects; consulting about support of investments; assistance in establishing and registering a company in Slovakia; real estate database and help in finding the required area.

Operating investors can also use SARIO services, including the following: identification of local suppliers and service providers; consulting on preparation and realisation of the company's expansion; support in relocation of the company, obtaining work permits or residence permits; support activities in the sphere of innovation, research and design work; networking.

The most important trend in the modern economy of the country, SARIO considers the creation of job positions with high added value. Therefore, in the issues of scientific research, SARIO activity aims to transform Slovakia into a technological and innovation centre of Central Europe. As for the issues support of scientific research, SARIO offers: supporting activities for the development of the Slovak innovation environment and innovative researches; establishing links with existing national and foreign investors; establishing links between the innovative potential of Slovak enterprises and the needs of investors in order to transfer advanced technological processes into production; stimulating of foreign investors to invest in Slovakia; analysing of local investment opportunities for national and foreign investors in order to establish joint ventures.

It is important to emphasize that all services to exporters, current and potential investors are provided by SARIO free of charge that is in the Slovak Republic they are one of the active forms of state support for exporters and investment activities.

In the modern paradigm of promoting Slovakia's national interests in the area of international economic relations, personnel providing for economic diplomacy are of great importance. It should be noted that the criterion of professional competencies was and in some cases remains the subject of discussion by scientists and representatives of state structures endowed with the functions of economic diplomacy. The need for orientation in economic diplomacy to professionals with proper education, experience and professional qualifications has been repeatedly emphasized by Polish scientists and practitioners. The selection of personnel who would ensure the effective implementation of tasks, primarily economists, financiers and lawyers is important for this area of work. This approach is the fundamental basis of effectiveness and efficiency of economic diplomacy and includes two components: the first is the formation of a professional resource at the level of professional training during the educational process in higher education institutions and later at specialized seminars, forums, trainings; the second is the direct formation of the staff of national structures of economic diplomacy both within the country and abroad.

A special feature of Slovakia is that it is one of the few countries where higher education institutions provide training for specialists in this profession. Thus, the faculty of international economic relations in the University of Economics in Bratislava study professionals in speciality "Economic diplomacy" (University of Economics in Bratislava, 2020). Hereby the training programme covers the entire range of academic disciplines required in the practical work of economic diplomats. In Ukraine, there is nothing like this in this regard, and the Diplomatic Academy under the Ministry of Foreign Affairs in recent years 
turned from a full-fledged educational institution for training specialists for the diplomatic service into advanced training courses, where at the best one/twoweek seminars or two-day trainings are held (Center of professional training, 2020).

In terms of direct staffing of economic diplomacy, Slovakia also has its own features. Thus, among the functional responsibilities of the Ministry of Economy of the Slovak Republic, its role and authority in the implementation of professional providing of the structures of Slovak economic diplomacy should be emphasized. In particular, the Ministry of Economy manages and controls the activities of foreign missions, which are an integral part of the Slovak embassies, professionally, financially, economically and by personnel. These issues are coordinated with the Ministry of Foreign and European Affairs of the Slovak Republic. In addition, training of specialists in the field of foreign trade is provided by the Slovak Investment and Trade Development Agency (SARIO).

The efficiency and effectiveness of the country's economic diplomacy in issues of protecting national interests requires appropriate methodological reasoning and content. An important element in this segment is the appropriate organization and planning of the main activities of economic diplomacy. Thus, at the level of the Ministry of Economy and the Ministry of Foreign and European Affairs of the Slovak Republic, a list of the main activities in the country's foreign and European policy is determined, adopted and accepted for execution annually. These activities consist of four blocks: 1) a safe and democratic world; 2) European politics; 3) economic diplomacy; 4) services for citizens and modern diplomacy.

In the part of the economic diplomacies' events for recent years there were highlighted the following: energy security (ensuring the security of supply of energy raw materials and the continued diversification of routes and sources), creating conditions for establishing partnerships between Slovak firms with foreign companies, promoting and establishing contacts of Slovak innovative enterprises with foreign partners, developing existing and potential investment and trade relations with the EU and neighbouring countries, additional work on increasing exports and investments from China, India, Japan, Republic of Korea, Singapore, Brazil. In addition, priority activities on economic diplomacy include: the preservation of security and profitability of way of natural gas transportation to Europe, facilitating access of Slovak goods and services to international markets, activation of work with international economic organizations according to new trends of development, expansion of investment and trade relations with the EU, increasing export efforts in the markets of named above countries.

\section{Conclusions}

The research and analysis of the issues under consideration performed by us give grounds to assert that the economic diplomacy of the Slovak Republic within the framework of its membership in the EU is an important tool for the success of the country's foreign economic policy, ensuring its export expansion in international markets and intensive investment cooperation with foreign investors.

Slovakia's high level of export orientation of GDP is largely ensured by the use of effective mechanisms for supporting and promoting national products on foreign markets. The country implements the paradigm of ensuring the effectiveness of foreign economic relations within the EU and the Visegrad Four, as well as within other countries. A characteristic feature of this paradigm in recent years has been a pronounced pro-export policy of the state, the implementation of which is largely ensured by means of economic diplomacy. Accordingly, there have been formed mechanisms for promoting Slovak national interests and ensuring international economic activity, which include normative and legislative, functional and institutional, personnel and methodological components. In this connection, the role of the state and authorized institutions responsible for organizing and coordinating the use of economic diplomacy tools and full-fledged assistance to foreign economic entities remains decisive.

The current practice of staffing institutions of economic diplomacy in Slovakia, which is based on qualified training of economic diplomats within the framework of a full-fledged university programme, is particularly notable. In the future, professional support of the structures of Slovak economic diplomacy and its personnel, professional, structural and financial support by the Ministry of economy are an absolute requirement.

The investigated mechanisms and practices of promoting Slovakia's international economic activity in foreign economic relations deserve the attention of the relevant state structures of Ukraine regarding the unification of regulatory standards and the formation of appropriate mechanisms for protecting national interests, including in the context of the implementation of The Ukraine-European Union Association Agreement.

Based on the relevance of the considered problems in foreign economic activity in the context of a globalized world economy and growing competition in international markets, there are enough reasonable grounds to propose the imperatives of Slovakia implemented in this area regarding regulatory, functional, institutional, personnel and methodological support for the promotion of national interests in foreign markets for consideration and implementation in the national practice of interested countries. 


\section{References:}

Bayne, S. (2010). Economic Diplomat. Durham: The Memories Club

Bayne, N., and Woolcock, S. (2007). The New Economic Diplomacy. London: Ashgate.

Bergeijk, P. A. G. von, Okano-Heijmans, M., \& Melissen, J. (Eds.) (2011). Economic Diplomacy: Economic and Political Perspectives. Leiden: Martinus Hijihoff Publishers.

Bohac, R., \& Lipkova, L. (2016). Cataracts of globalization and the economic diplomacy of small states. Economic Annals-XXI, 159(5-6), 16-19.

Centre of professional training (2020). Available at: http://da.mfa.gov.ua/cvt/ (in Ukrainian)

Cooper, A. F., Heine, J., \& Thakur, R. (Eds.) (2013). The Oxford Handbook ofModern Diplomacy. Oxford: OUP Oxford. Economic Club of New York (2011). Remarks by Secretary of State Hillary Rodham Clinton. (October 14, 2011). Available at: http://www.state.gov/secretary/rm/2011/10/175552.htm

Fabus, M. (2014). Foreign direct investment and its impact of the Slovak Republic's economy. Economic Annals-XXI, 9-10, 42-45.

Glasser, B. (2012). China's Coercive Economic Diplomacy: A New and Worrying Trend. Center for Strategic and International Studies. 2012 (August 6). Available at: http://csis.org/publication/chinas-coercive-economicdiplomacy-new-and-worrying-trend

Juma, C. (2013). Africa and Brazil at the Dawn of New Economic Diplomacy. The Belfer Center for Science and International Affairs (Kennedy School of Government). 2013 (February 26). Available at: http://belfercenter.ksg.harvard.edu/publication/22793/

Kashtyakova, E. (2017). Development of Foreign Trade Relations between Slovakia and Russia under the Influence of Geopolitical Changes. Trade policy, 2/10, 41-95.

Kurucz, M. (2018). Economic and political factors affecting attitudes of Slovakia and Hungary towards the future of the EU. Economic Annals-XXI, 172(7-8), 28-31.

Marchichiakova, L. (2014). Aims of foreign policy of Slovakia for 2014. Available at: http://rsi.rtvs.sk/russkiy/ clanky/tema-dnja/22538/celi-vnesnej-politiki-slovakii-na-2014-god

Ministry of Foreign Affairs and European Affairs of the Slovak Republic (2017). The first meeting of the Council of the Government of the Slovak Republic to support exports and investments in 2017. Available at: https://www.mzv.sk/podnikajme_v zahranici/detail/-/asset_publisher/Iw1ppvnScIPx/content/prverokovanie-rady-vlady-slovenskej-republiky-na-podporu-exportu-a-investicii-v-roku-2017

Ministry of Foreign Affairs and European Affairs of the Slovak Republic (2018). The first meeting of the Council of the Government of the Slovak Republic to support exports and investments in 2018. Available at: https://www.mzv.sk/podnikajme v zahranici/detail/-/asset publisher/Iw1 ppvnScIPx/content/prverokovanie-rady-vlady-sr-na-podporu-exportu-a-investicii-v-roku-20 $\overline{18}$

Ministry of Foreign Affairs and European Affairs of the Slovak Republic (2020). Statute of the Council of the Government of the Slovak Republic for the Promotion of Exports and Investments. Available at: https://www.mzv.sk/documents/

Ministry of Foreign and European Affairs of the Slovak Republik (2015). Focus of foreign and European policy of the Slovak Republic for the year 2015. Available at: https://www.mzv.sk/documents/10182/2198827/2015

Ministry of foreign and European affairs of the Slovak Republik (2016). Focus of foreign and European policy of the Slovak Republic for the year 2016. Available at: https: //www.mzv.sk/documents/10182/2198827/2016

Moons, S., \& Van Bergeijk, P. A. G. (2009). Economic Diplomacy and Economic Security, New Frontiers for Economic Diplomacy. Instituto Superior de Ciéncias Sociais e Politicas.

Rose, A. K. (2007). The Foreign Service and Foreign Trade: Embassies as Export Promotion. The World Economy, vol. 30, no. 1, pp. 22-38.

Slovak Investment and Trade Development Agency - SARIO (2020). Available at: http://www.sario.sk (in Slovak) Statistical office of the Slovak Republic (2019). Foreign trade of the Slovak Republic. Available at: http://statdat.statistics.sk/ Ministry of Economy of the Slovak Republic (2014). Strategies of external economic relations of the Slovak Republic for the period 2014-2020. Available at: http://www.economy.gov.sk/obchod/podpora-exportu/ strategia-vonkajsich-ekonomickych-vztahov-sr-na-obdobie-2014-2020

Ministry of Economy of the Slovak Republic (2020). Statute of the Ministry of Economy of the Slovak Republic. Available at: http://www.economy.gov.sk/uploads/files/ejpaZTT9.pdf

The World Bank (2020). Slovak Republic. Available at: data.worldbank.org/indicator/

United Nations Conference on Trade and Development (2012). World Investment Report Foreign Direct Investment and the Challenge of Development. United Nations, New York and Geneva.

University of Economics in Bratislava (2020). Available at: https://fmv.euba.sk/studium/bakalarske-a-inzinierskestudium/zakladne-informacie

Van Bergeijk, P. A. G. (2009). Economic Diplomacy and the Geography of International Trade. North Hampton: Edward Elgar Publishing.

Woolcock, S. (2016). European Union Economic Diplomacy. The Role of the EU in ExtarnalEconomic Relations. L.: Routledge. Yankiv, M., Flissak, K., \& Kozłowski A. R. (2020). Dyplomacja w zagranicznej wspótpracy gospodarczej [Diplomacy in foreign economic cooperation]. Warszawa: CeDeWu. 